\title{
Justyna Suchanek
}

$M A$, University of Gdansk, Poland

https://orcid.org/0000-0003-2505-1472

\section{SUCCESS FACTORS FOR THE DEVELOPMENT OF URBAN BIKE SYSTEMS}

\begin{abstract}
City bike systems are an important element of sustainable urban mobility. The first concept appeared in the world in the second half of the $20^{\text {th }}$ century and since then the popularity of this form of transport has been growing all the time. The development of public bicycle systems increases cycling mobility. In recent years, systems have changed constantly, adapting to the needs of users. More and more advanced technological solutions are being introduced and they force continuous development and verification of previous assumptions. The high popularity of city bike systems has influenced the interest of researchers in measuring their success. The basis for creating the classification should be striving to meet the transport needs of potential system users and expectations related to new means of transport.
\end{abstract}

Keywords: success factors, city bike systems, transport innovations, sustainable urban mobility, endogenous factors, exogenous factors.

JEL Codes: R40, R42, Q58

\section{Introduction}

All over the world, there is a great deal of interest in ecological modes of transport due to progressive climate change, increased air pollution and carbon dioxide emissions into the atmosphere. Therefore, the last few decades are a time of lively development of city bike systems, representing the mainstream economy of sharing, which is based on the assumption of more efficient use of resources by sharing them. The creation of shared mobility systems contributes to the development of the distribution of goods and services in accordance with the idea of a sustainable transport development policy (Botsman, Rogers, 2011). 
Public bike projects have been implemented in cities that have developed in many directions. Some took the form of technically advanced systems with thousands of bicycles and stations, some were retained as smaller systems with a lower degree of use, others ended their activities due to incorrect model assumptions.

However, there is still a lack of information on the success factors for the implementation of individual systems, which are still innovations on the transport services market. The overall increase in the share of cycling and the spread of bicycle rental systems prompted researchers to attempt to identify key factors determining the development of public rental companies. Determining the success factors of city bikes is a challenge because there is a diverse approach to this issue in the literature.

The purpose of the article is to present and classify the factors that create the success of city bike systems, which is one of the foundations for inferring further perspectives for the development of public bike in the world.

\section{The role of success factors for the development of city bike systems}

The success of city bike systems can be seen from different perspectives. In some cities, the indicator of success can be revenues generated from the system, economic efficiency measured by the level of profit, the difference in bicycle traffic volume measured before and after opening the rental or the number of rentals in the system per capita. In others, one may consider system durability and long-term maintenance. An important element in studying the success of city bike systems is to understand users' transport behaviors and preferences. City bike systems must, on the one hand, be economically justified, but on the other, encourage the potential user to use it through the high availability of bikes, an efficient relocation system or an appropriate station density. In addition, urban policy should focus on reducing the demand for travel by car for travel on foot, by bicycle or by public transport (Burnewicz, 2013).

In recent years, researchers have been constantly looking for answers to questions on how to determine the optimal service area, size and number of stations, ways of relocating and storing bicycles, as well as the real impact of shared mobility services on the city's transport system. Studies conducted in the USA and Canada by S. Shaheen indicate that the purpose of cyclists' travel is mainly commuting to work or place of study, and the duration of a single ride does not exceed 30 minutes (Shaheen et al., 2014). E. Fishman on the basis of conducted research indicates comfort as the most important factor in choosing a bicycle as a means of transport (Fishman et al., 2015). City residents, in particular, value in city bike systems saving time and money (the first 20-30 minutes of renting a bike for free), independence and convenience (no need to wait for transport and adapt to timetables), psychological comfort (no worries about theft and no maintenance fees) and travel pleasure (Dąbrowski, Fall, 2015).

Elements of the city bike system are already adapted at the design stage to the conditions prevailing in a given city. Among others, bikes with a solid and non-standard 
design, docking stations (up to the third generation), and advanced IT systems are being introduced. All elements of the strategy are developed by representatives of city authorities, operators and specialized companies (Pai, Pai, 2015).

An important factor contributing to the development of city bike systems is the amount of charges for renting a bike. A too high charge discourages from using the system. The distance between the docking stations depends on the size of the service area of the entire system and the size of the city. In addition, when analyzing the asymmetrical travel time, attention should be paid to the quickly appearing shortage of bicycles at one station and excess at others. The method of bicycle relocation is one of the most important elements of the whole system.

J. Olson, P. Goff, S. Simms linked the success of city bike systems with (Olson, Goff, Simms, 2011):

- service area,

- connections with other means of transport, including joint tickets for bike rental and urban transport,

- seasonality of operation,

- type of operating entity,

- station availability,

- bicycle infrastructure and equipment quality,

- efficiency of bicycle maintenance and repair,

- relations with advertisers.

Much research has been devoted to the benefits of using a bicycle in urban travels. Factors determining the success of the city bike system are presented in Table 1.

Table 1 . Success factors of a city bike

\begin{tabular}{|c|c|}
\hline Category & A conditioning factor \\
\hline \multirow{7}{*}{$\begin{array}{l}\text { Features and general } \\
\text { system characteristics }\end{array}$} & The design, the look and quality of the system bicycle \\
\hline & Number of docking stations and bicycles \\
\hline & Convenience regarding the rental and return procedure \\
\hline & Availability of docking stations (location) \\
\hline & Charging system \\
\hline & The efficiency of the system and solving problems of users \\
\hline & Bicycle maintenance and relocation system \\
\hline \multirow[t]{6}{*}{ Environmental factors } & The quality of bicycle infrastructure \\
\hline & Bike path identification (road signs) \\
\hline & Road lighting \\
\hline & Information system on the number of bikes at stations \\
\hline & Quality of public transport services \\
\hline & Sanitary facilities \\
\hline \multirow[t]{3}{*}{ Exogenous factors } & Climate \\
\hline & Geography and topography of the area \\
\hline & Communication behaviours \\
\hline \multirow{2}{*}{$\begin{array}{l}\text { User profile } \\
\text { and transport } \\
\text { preferences }\end{array}$} & Gender \\
\hline & Economic status \\
\hline
\end{tabular}

Source: Pai, Pai 2015 
In 2011, the three-year OBIS project (Optimizing Bike Sharing in European Cities) was completed, which was a response to the dynamic development of public bike systems and the launch of the Bicing system in Barcelona and Velib in Paris. The project analyzed the differences between existing city bike systems in Europe and identified factors that affect the functioning of systems with the division into endogenous and exogenous factors. A detailed characteristics of success factors is shown in Table 2.

Table 2. Division of success factors of city bike systems into endogenous and exogenous

\begin{tabular}{|l|l|}
\hline \multicolumn{1}{|c|}{ Endogenous factors } & \multicolumn{1}{c|}{ Exogenous factors } \\
\hline Material solutions & Size of the city \\
\hline Equipment and technology & Climate \\
\hline Organization of the manner of providing services & Mobility behaviours \\
\hline Institutional solutions & Population density \\
\hline Operator type & Demographic factors \\
\hline Contracts and Ownership & Economic factors \\
\hline Sources of funding & Geography and topography of the area \\
\hline & Existing infrastructure \\
\hline & Financial situation \\
\hline & Political situation \\
\hline
\end{tabular}

Source: Optimising Bike Sharing in European Cities 2011

\section{Characteristics of city bike systems and organization of service provision}

The characteristics of the bicycle system and the organization of the provision of services are basic information on the size of the system, availability, registration and login of users, the system of charges, returns and rentals. Data on this subject are provided by operators including Nextbike, BikeU and Romet Rental Systems on websites, as well as in the form of annual and quarterly reports.

One of the factors of the organization of the service is the size and density of the system, which depends on the size of the expected demand and the planned area of the service. The city bike system has a chance of surviving if the scale of the system is determined taking into account the relevant urban parameters and assumptions. The scale of the system consists of: the number of bicycles, the number of stations (in the case of the station model), the number of docking points. Active bikes can be considered as the number of active bikes in the systems, excluding the number of bikes submitted for maintenance or stored in the warehouse.

The number of stations depends on the size of the service area. The experience of large European systems such as Bicing in Barcelona or Velib in Paris shows that the distance between stations should not exceed 300 meters. It is a distance that can be covered on foot in a short time. Larger distances between stations can stop users 
from using this form of urban mobility on a daily basis and thus affect the premature termination of the system (Optimising Bike Sharing in European Cities, 2011).

The density of city bike station locations depends on transport modes. Stations should dominate in areas where there are a large number of public institutions (cultural centers, offices), educational centers, in particular universities, enterprises and shopping centers. The station density is determined by each city individually. An important motivation in determining the correct location of stations is to reduce relocation costs, because when the stations are closer to each other it is easier to transport bikes from one station to another. Densely located stations also make the system more visible and accessible to users. The importance of station density in the development of city bike systems has been highlighted in Daddio and Rixey research, which showed that the distance between city bike stations is an important factor in the number of rentals (Daddio, 2012).

Not only the number, but also the size of the bicycle stations must be appropriate. Empty stations and stations with broken bicycles cause user frustration and reluctance to regularly use the system. In popular locations, e.g. in the central part of the city or in the vicinity of interchanges, the demand for bicycles is greater. In large European cities, such as Paris or Vienna, the average number of docking points per station is about 20. In medium-sized cities such as Parma, Montpellier or Warsaw, the number of docking points per station is about 15.

City bike systems operate within the network, which is the number of connected stations. Each new station should be planned so that its location matches the previously created stations as a new destination and its creation leads to a reduction in the average cost of all stations in the network. The introduction of small systems is unprofitable due to the high cost of station construction and at the same time limited availability for users. The number of years of system operation can also be a sign of success, the longer the system's operation, the better the chances of survival and the guarantee of further functioning.

City bike systems are designed to encourage short-term rentals, which is why in most systems there is a free use period of 20-30 minutes. Then the cost of renting a bike increases exponentially until the daily limit is reached. There are also systems in which the paid period starts from the first minute and the charge increases with the duration of the rental. In both types of systems, a short, regular city trip to the workplace or school is promoted. In the system with a free period of use, the goal is to increase accessibility, in the system without a free rental period, the goal is regular urban travel made by bicycle as part of the subscription journey (Transport publiczny, 2017).

\section{Contracts and financing of city bike systems}

In the area of contracts and system financing, two categories of costs are distinguished: investment and operating costs and costs related to the operator contract. The first cost category includes infrastructure costs and running costs.

The cost structure of the city bike system depends on the number of rentals and the size of the system. The greater the number of rentals per bike, the lower 
the average cost of renting a bike. Other running costs are mostly variable costs. The greater the number of bicycle rentals, the greater the costs associated with servicing, relocation, maintenance and repairs.

The main sources of revenue for the city bike system are registration charges and usage charges (after free rental time). Most systems are not able to finance themselves because the revenues from rentals do not cover the costs incurred, depending on the contract with operators, there is co-financing with the help of subsidies from public local governments, advertising contracts and sponsorship sale of bicycle stations. The estimation of all costs is not possible in detail due to the trade secret of city bike system operators.

The unit cost of the subsidy from public funds depends on (EU Consult, 2016):

- the duration of the contract,

- system scale,

- business model, scope of service and quality requirements for the service,

- the results of the tender procedure taking into account all of the above factors, as well as inflows from sources other than the state subsidy, the budget possible to be allocated for the creation and maintenance of the system by the local government, offers submitted by competitors, own expansion plans.

System costs include costs related to the system construction and operating costs. The costs of building a city bike system include: costs of building stationary and mobile infrastructure as well as an IT system. Stationary infrastructure includes cost items determined by:

- bicycle parking places (designated areas, most often bike rental and return stations with bicycle stands),

- city bike system terminals (devices used to make a reservation for a user of a city bike system and to fund a user's account with appropriate funds),

- advertising space (part of the parking infrastructure and terminals used to generate advertising revenue),

- monitoring (cameras for observing and recording traffic at bicycle stations).

Costs are generated by renting or buying storage areas to manage the system, create diagnostic and repair stations and stations with the right equipment. Mobile infrastructure includes:

- bicycles (equipment of special design, equipped in the latest systems with electronic surveillance system, electric lock, proximity and RFID card reader and NFC communication module),

- cars (trucks and vans for transporting bicycles and structural elements),

- service bikes for the relocation of individual bikes and minor field repairs.

The costs of building an IT system include the services of: geolocation, rental and reservation system with a dedicated mobile application, website, service system and central transport database. Operating costs are all costs related to commercial and technical customer service as well as repairs and maintenance of high quality technical condition of owned bikes. Costs include:

- bicycle relocation (regular transport of bicycles between stations in order to maintain maximum bicycle availability),

- servicing (ensuring technical efficiency, including repairs, cleaning, inspections, replacements, renewal of equipment), 
- marketing and customer service (promotional activities, advertising materials, organization of events),

- IT (IT systems support and software development),

- maintenance of bicycle parking spaces (cleaning, lighting),

- other (employee remuneration, system operation, storage space maintenance, insurance, accounting).

The cost structure of the Bicing city bike system in Barcelona is shown in Table 3.

Table 3. Costs of the Bicing city bike system in Barcelona

\begin{tabular}{|l|c|l|c|}
\hline \multicolumn{1}{|c|}{ Type of system startup cost } & $\begin{array}{c}\text { Share in total } \\
\text { costs [\%] }\end{array}$ & \multicolumn{1}{|c|}{ Type of system operation cost } & $\begin{array}{c}\text { Share in total } \\
\text { costs [\%] }\end{array}$ \\
\hline $\begin{array}{l}\text { station construction, docking } \\
\text { points, terminals, ground works } \\
\text { and cabling }\end{array}$ & 70 & bicycle relocation & 30 \\
\hline bicycles & 17 & $\begin{array}{l}\text { bicycle maintenance } \\
\text { and servicing }\end{array}$ & 22 \\
\hline logistics & 6 & system back-up & 14 \\
\hline communication & 5 & administration & 13 \\
\hline administration & 2 & $\begin{array}{l}\text { exchange (of bicycles, docking } \\
\text { points) }\end{array}$ & 1 \\
\hline
\end{tabular}

Source: Optimizing Bike Sharing in European Cities 2011

The revenues of the city bike system consist of:

- revenues from users related to bicycle rentals,

- revenues from advertisements placed on bicycles, service cars, websites, in a mobile application on mobile devices and built infrastructure,

- other operator revenues.

Adoption of the appropriate cost and revenue model of the city bike system determines the success of the investment. Important from the development point of view is the optimization of the investment in line with users' expectations, infrastructure capabilities, as well as an accurate estimate of the costs of bicycle stations, warehouse space, service stations and unit purchase of bicycles. Assumptions about operating costs are also essential for the system's success. These costs define the cost of system maintenance, bike relocation, service station maintenance, storage space maintenance, bicycle storage, spare parts costs and bicycle maintenance.

\section{Macroeconomic and socio-demographic factors in shaping services}

When considering the difference in the levels of development of various cities, their economic strength plays an important role, which is calculated on the basis of the amount of public revenues in given areas. The competitiveness of cities is influenced by the diversity of their economic structures, transport accessibility, scientific and research facilities and business-related environment. These features are conducive to entrepreneurship and the development of innovative, alternative 
means of transport, which can undoubtedly include a city bike. On the other hand, the low level of overall development reduces the attractiveness of the area and the slower development in relation to others. All development processes that take place in the city are highly complex, hence the isolation of factors that may affect the development of the city bike system is complicated.

Socio-demographic factors influence individual transport choices and behavior of travelers. Variables such as the number of commuters, employment status and number of vehicles in the household are just some of the key factors needed to establish travel patterns and create a travel model. The study of basic demographic elements, such as population density, average income per capita, and level of education allows a better understanding of the motivation of people using bicycles and identification of potential users of the system.

In cities with higher population density, solutions are needed to improve mobility and to reduce the number of trips made by car. One of the alternative means of transport is a city bike, the use of which is a good way to reduce road traffic, as well as reduce exhaust emissions. The service area and station location is planned on the basis of the population density indicator and such matching is one of the conditions for system development (Portal samorządowy, 2014). There is a greater demand for a station located in a location with a higher population density due to the proximity of the place of rental to a larger number of users. Population density is also negatively correlated with the use of a passenger car (Dębowska-Mróz, Kacprzak, Zięba, 2016). In Lyon, the assumption is that one bicycle will be available per 100 inhabitants, stations will be located every 300 meters and the free first half hour ride set. The system is successful and each bike is rented over 7 times a day (Polska na rowery, 2011).

Users of the city bike system are mainly working people who use transport to get to the workplace, students who use the city bike to get to the place of study, tourists using the bicycle for tourism purposes, and people commuting to the integration nodes and transferring there on buses / trolley buses / trams. The location of the city bike station should be planned taking into account the pattern of morning commutes and afternoon returns from work / study.

The share of costs associated with owning a car is high for households, which is why residents are looking for alternative forms of travel to the workplace, study or recreation. Research indicates that more cycling communities are being created in areas with a higher population with higher education. Residents are better educated in terms of healthy and ecological lifestyle, there is also a greater awareness of the risks associated with air pollution and carbon dioxide emissions into the atmosphere.

\section{Transport and communication as well as climatic and geographical factors in shaping city bike systems}

The city's cycling infrastructure is a factor of success and at the same time the basis for the dynamic development of the city bike system. City bike systems are a significant complement to public transport. The effects of implementing the city 
bike system mention the increase in the number of public transport passengers, due to the significant expansion of the service area. In cities without such a system, residents reach a bus stop about $500-1000$ meters away. When the system is started, the range of stops increases and amounts to about 4-5 kilometers (Chalfen, Kamińska, 2016). The use of a city bike may also depend on the number of cars in the household. People with higher incomes most often have more vehicles in the household, which may result into a smaller need to replace travel by car using alternative forms of transport (Transport publiczny, 2016).

City bike systems are also a substitute for travel modes such as walking and cycling. The possibility of renting a bicycle and using it on a one-way journey without incurring costs associated with the maintenance of the bicycle and storage increases the efficiency of travel of people who do not have their own bike or have their own bike, but encounter their problems associated with transporting it in available means of public transport (lack of space in bus, no security guarantee of leaving the bike around interchange places). The development of city bike systems should be related to the possibility of moving between intermediate destinations, i.e. place of residence / work and bus stop / station. A city bike allows to combine different modes of transport and provides higher mobility than standard public transport.

The description of climatic and geographical factors of cities is an important element of studies on the possibilities of building and developing city bike systems. Climatic parameters of areas, such as climate variability or insolation, temperatures (annual, seasonal and daily amplitude), wind speed and precipitation are examined. Interpreting the data, one can refer to a broader geographical context and check whether the selected parameters are similar to the parameters of other urban centers in Poland and European countries with a similar geographical location. Taking climate conditions into account allows for more effective planning of solutions and increases the chances of success. Geographic factors relevant to the emergence and survival of a city bike also include the occurrence of elevation and fall. They are of importance in planning a station ( $3^{\text {rd }}$ generation) of a city bike and make it difficult to relocate bicycles (most of the trip down). However, these problems are slowly solved by the introduction of electric bicycles.

The climate and topography of the terrain also determine when and how people use the bicycle as a means of transport. The weather affects the demand for bicycles, which is why the vast majority of European systems operate seasonally, bicycles are available in the spring, summer and autumn months, and stored in the winter season. Changes in this area would be ineffective because users in the cold months do not use the bicycle and the equipment is not adapted to ice and snow. Winter activity barriers also include relocation problems, bicycle maintenance and repairs.

At the same time, the importance of social perception of the seasons as attractive or unattractive for bicycle use should be indicated. Initially, users pointed to spring and summer as an attractive period, however, the latest European research analyzing traffic behavior in comparable cities in terms of climate, i.e. Berlin, Copenhagen or Helsinki in the field, indicates a change in attitudes and increased interest in cycling also during the colder seasons (EU Consult, 2016b). 


\section{Classification of success factors for city bike systems development}

There are two main groups of success factors for the development of city bike systems, exogenous and endogenous, which complement each other, consequently enabling the maintenance and development of systems (Warczak, 2015). Table 4 presents endogenous factors for the success of the development of city bike systems together with selected measures in each category and subcategory.

Table 4. Endogenous factors conditioning the success of a city bike

\begin{tabular}{|c|c|c|c|}
\hline \multicolumn{3}{|c|}{ Variable } & Measure \\
\hline Dependent & \multicolumn{2}{|l|}{ annual rentals } & $\begin{array}{l}\text { average annual number of rentals of } 1 \text { city } \\
\text { bike }\end{array}$ \\
\hline \multirow[t]{14}{*}{ Independent } & \multirow{5}{*}{$\begin{array}{l}\text { Characteristics } \\
\text { of the bicycle } \\
\text { system } \\
\text { and organization } \\
\text { of the provision } \\
\text { of services }\end{array}$} & \multirow[t]{3}{*}{ system size } & number of bicycles per 1000 inhabitants \\
\hline & & & number of stations per 1000 inhabitants \\
\hline & & & average number of bikes at the station \\
\hline & & charges & existence of a free-of-charge period \\
\hline & & time of operation & number of seasons of system operation \\
\hline & \multirow{9}{*}{$\begin{array}{l}\text { Contracts } \\
\text { and financing }\end{array}$} & \multirow[t]{3}{*}{ construction costs } & cost of building 1 station \\
\hline & & & cost of building 1 service station \\
\hline & & & average bicycle price \\
\hline & & \multirow[t]{4}{*}{ operating costs } & annual cost of maintaining 1 station \\
\hline & & & annual cost of maintaining 1 bicycle \\
\hline & & & annual cost of storing 1 bicycle \\
\hline & & & annual cost of servicing 1 bicycle \\
\hline & & \multirow[t]{2}{*}{ other } & average cost of salary per 1 employee \\
\hline & & & amount of city subsidy (\% of total) \\
\hline
\end{tabular}

Source: own study.

Exogenous factors are characteristic for a given city, they are not susceptible to short-term changes. Table 5 presents exogenous factors for the success of city bike systems development.

Table 5. Exogenous factors conditioning the success of a city bike

\begin{tabular}{|l|l|l|l|}
\hline \multicolumn{2}{|c|}{ Variable } & \multicolumn{1}{c|}{ Measure } \\
\hline Dependent & \multicolumn{2}{|l|}{ annual rentals } & $\begin{array}{l}\text { average annual number of city bike } \\
\text { rentals }\end{array}$ \\
\hline Independent & $\begin{array}{l}\text { Macroeconomic } \\
\text { factors }\end{array}$ & city budget & total city budget revenue per capita \\
\cline { 3 - 4 } & $\begin{array}{l}\text { total expenditure of the city budget per } \\
\text { capita }\end{array}$ \\
\cline { 2 - 4 } & $\begin{array}{l}\text { Socio-demographic } \\
\text { factors }\end{array}$ & $\begin{array}{l}\text { population } \\
\text { density }\end{array}$ & population density per person per $1 \mathrm{~km}^{2}$ \\
\cline { 3 - 4 } & households & $\begin{array}{l}\text { non-working population per } 100 \text { working } \\
\text { people }\end{array}$ \\
\cline { 3 - 4 } & & birth-rate per 1,000 people \\
\hline
\end{tabular}




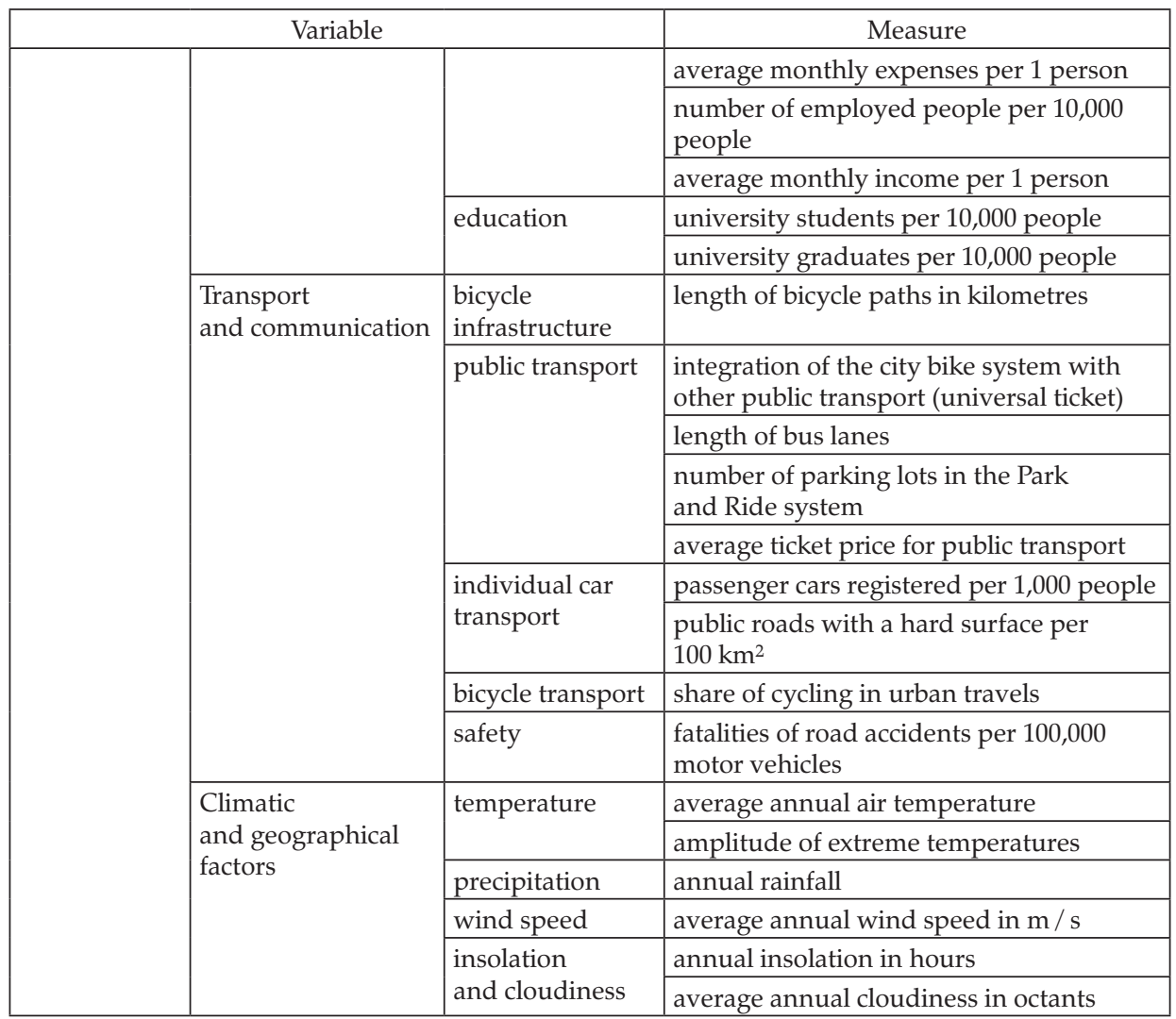

Source: own study.

\section{Conclusions}

In accordance with the principle of sustainable transport development, it is assumed that the share of ecological forms of urban mobility in the city's transport system will increase, including shared mobility, an example of which is the city bike system. The analysis of the success factors for the development of city bike systems is an essential element of operation before the system is implemented and integrated with the transport system in the city. For the efficient functioning of urban transport, it is necessary to search for transport innovations and implement them based on the optimal functioning model. Taking into account many different factors allows to reduce the risk of making a mistake already at the investment design stage.

\section{References}

Botsman R., Rogers R., 2011. What's min eis yours: How collaborative consumption is changing the way we live, HarperCollins Publishers, London. 
Burnewicz J., 2013. Nouvelles mobilités et villes intelligentes en Pologne, l'Observatoire des Politiques et des Stratégies de Transport en Europe, Paris

Chalfen M., Kamińska J., 2016. Analiza wykorzystania roweru miejskiego we Wrocławiu, Autobusy, nr 6

Dąbrowski M, Fall M., 2015. Jak rowery miejskie tworza "smart cities" [w:] Biata Księga Mobilności, Nextbike, Stowarzyszenie Transportu Publicznego, Transport Publiczny, http:// transport-publiczny.pl/BKM/BialaKsiegaMobilnosci2015.pdf (accessed 3 October 2019)

Daddio D. W., 2012. Maximizing Bikesharing: An Empirical Analysis of Capital Bikeshare Usage, University of North Carolina at Chapel Hill

Dębowska-Mróz M., Kacprzak M., Zięba P., 2016. Infrastruktura rowerowa jako element systemu transportowego Radomia, Autobusy, nr 12.

Drucker P., 2000. Zarzadzanie w XXI wieku, Muza S.A., Warszawa.

EU Consult, 2016. Koncepcja budowy systemu Szczecińskiego Roweru Metropolitalnego. http://www.zit-som.szczecin.pl/images/dokumenty/Koncepcja_budowy_SRM.pdf (accessed 14 October 2019)

EU Consult, 2016. Studium koncepcyjne Systemu Roweru Metropolitalnego dla Obszaru Metropolitalnego Gdańsk - Gdynia - Sopot. http://www.metropoliagdansk.pl/upload/ files/Studium_koncepcyjne_SRMOMGGS\%20wersja\%204_0.pdf (accessed 14 October 2019)

Fishman E., Washington S., Haworth N., Watson A., 2015. Factors influencing bicycle share membership: An analysis of Melbourne and Brisbane, Transportation Research Record, vol. 71, https://doi.org/10.1016/j.tra.2014.10.021

Olson J., Goff P., Simms S., 2011. City of Providence Bicycle Share Feasibility Study Final Report, Design for City of Providence

Optimising Bike Sharing in European Cities, 2011. http://mobility-workspace.eu/wp-content/ uploads/OBIS_Handbook_PL.pdf (accessed 27 October 2019)

Pai J. T., Pai S. Y., 2015. User Behaviour Analysis of the Public Bike System in Taipei, International Review for Spatial Planning and Sustainable Development, vol. 3, nr 2, https://doi. org/10.14246/irspsd.3.2_39

Penc-Petrzak I., 2010. Planowanie strategiczne w nowoczesnej firmie, Wolters Kluwer, Warszawa

Polska na rowery, 2011. http://polskanarowery.sport.pl/msrowery/1,105126,10706963, Rower_miejski_dlaczego_jednym_sie_udaje_a_innym.html (accessed 1 October 2019)

Portal samorządowy, 2014. http://www.portalsamorzadowy.pl/gospodarka-komunalna/ system-wypozyczalni-rowerow-musi-byc-dopasowany-do-miasta,60536.html (accessed 14 October 2019)

Shaheen S. A., Martin E. W., Chan N. D., Cohen A. P., Pogodzinski M., 2014. Public Bikesharing in North America during a Period of Rapid Expansion: Understanding Business Models, Industry Trends and User Impacts, Mineta Transportation Institute

Transport publiczny, 2016. http://www.transport-publiczny.pl/wiadomosci/ kopenhaga-rowerow-wiecej-niz-samochodow-53492.html (accessed 14 October 2019)

Transport publiczny, 2017. http://www.transport-publiczny.pl/wiadomosci/wavelo-kontr a-veturilo-dwa-pomysly-na-placenie-za-rower-54490.html (accessed 24 October 2019)

Warczak M., 2015. Endogeniczne i egzogeniczne czynniki rozwoju gospodarczego z perspektywy finansów gminy, Współczesna Gospodarka, vol. 6, nr 4, pp. 111-122

\section{Corresponding author}

Justyna Suchanek can be contacted at: suchanekjustyna92@gmail.com 